\title{
Sportcivil szervezetek - számok a támogatások növekedése mögött
}

\author{
GY. N. SZABAdos ${ }^{1}$, B. É. BÁCSNÉ2 ${ }^{2}$ V. FENYVES ${ }^{3}$, Z. BÁCS ${ }^{4}$, K. DAJNOKI ${ }^{5}$, S. KovÁCS 6 \\ ${ }^{1}$ Debreceni Egyetem, Gazdaságtudományi Kar, Szervezés és Kommunikáció Tanszék, \\ szabados.gyorgy@con.unideb.hu \\ ${ }^{2}$ Debreceni Egyetem, Gazdaságtudományi Kar, Sportgazdasági- és Menedzsment Tanszék, \\ bacsne.baba.eva@econ.unideb.hu \\ 32Debreceni Egyetem Gazdaságtudományi Kar, Kontrolling Tanszék, fenyves.veronika@econ.unideb.hu \\ 4Debreceni Egyetem Gazdaságtudományi Kar, Számviteli Tanszék, bacs.zoltan@econ.unideb.hu \\ ${ }^{5}$ Debreceni Egyetem, Gazdaságtudományi Kar, Emberi Erőforrás Menedzsment Tanszék, \\ dajnoki.krisztina@econ.unideb.hu \\ ${ }^{6}$ Debreceni Egyetem, Gazdaságtudományi Kar, Kutatásmódszertan és Statisztika Tanszék, \\ kovacs.sandor@con.unideb.hu
}

\section{A PUBLIKÁCIÓ ELKÉSZÍtÉSÉt a EFOP-3.6.2-16-2017-00003 SZÁMÚ PROJEKT TÁMOGATTA. A PROJEKT AZ EURÓPAI UNIó TÁMOGATÁSÁVAL, AZ EURóPAI SZOCIÁLIS ALAP TÁRSFINANSZíROZÁSÁVAL VALÓSULT MEG.}

Absztrakt. A KSH adatgyüjtési tevékenységének köszönhetôen a nonprofit szervezetekre vonatkozó átfogó adatok mind adatbázis, mind tájékoztató formájában elérhetőek. A gazdasági adatok között feltünik az az évről-évre hasonló nagyságú, domináns támogatási részesedés. Különös tekintettel a klasszikus civil szervezetekre ez egyértelmüen jelzi azt, hogy a szféra támogatáskitett és támogatásfüggő. Ezek a szervezetek ugyanis kimondottan alkalmasak támogatások fogadására. Tanulmányunkban szeretnénk másodelemzés révén rávilágítani arra, hogy a sporttal foglalkozó civil szervezetek/sportcivil szervezetek száma milyen összefüggésben van a támogatásokkal, különös tekintettel két specifikus támogatási formára, a NEA-ra és a TAO-ra vonatkozóan. Az eredmények arra utalnak, hogy van összefüggés a támogatások összegének növekedése és a sportcivil szervezetek számbeli növekedése között, és ez kifejezetten igaz az egyik legrégebbi és legújabb támogatási forma esetében is.

Abstract. As a result of the Hungarian Central Statistical Office's data collecting activity, comprehensive data of the nonprofit organizations are all available equally in the form of informative summary and database. Among the economic data the yearly similar, dominant subsidy portion seems to be striking. Particularly speaking about the classic civic organizations it seems to be obvious that this sphere is subsidy exposed and subsidy dependent. These organizations are specifically suitable to receive subsidies. In this study we aim to highlight the phenomenon how the number of sport related civic organizations/sports civic organizations are in relationship with the subsidies, with a special attention to two specific subsidy forms, the NEA and TAO. Results show that there is a relationship between the increase of the amount of subsidies and the rise of the number of sports profile civic organizations, and this is highly valid for one of the earliest and the latest subsidy forms. 


\section{Bevezetés}

A társadalmi felelősségvállalás alapvetően az üzleti szféra kötelezettségét jelenti annak érdekében, hogy a társadalom javára szolgáló döntéseket hozzanak és lépéseket tegyenek. Ez elsősorban a nonprofit szervezeteken keresztül valósul meg. A legtöbb Fortune 500-as szervezetnek vannak olyan pénzügyi alapjai, melyekkel nonprofit szervezeteket támogatnak [1]. A társadalmi felelősségvállalás a szervezetek morális, etikai és jótékony kötelezettségét jelenti. A nonprofit szektort független szektornak nevezi, az ide tartozó szervezetek egyedüli szerepet játszanak a társadalomban, és olyan szolgáltatásokat biztosítanak, melyek a társadalom vagy annak egy részének javát szolgálják, és jelentős mértékben támaszkodik önkéntesekre [2].

A magyarországi nonprofit és civil szervezetek 1987 utáni gazdasági és jogi szabályozásának lényegében öt fontos szakasza különböztethető meg [3]:

1, Nyitás időszaka 1987 és 1990 között.

2, 1991 és 1994 között az adókedvezmények általános megszorítása.

3, 1995 és 1996 között az állami irányítású szervezetek számára szelektív megszorítások és kivételes bánásmód kialakulása. Itt külön kiemelendő az 1996. évi CXXVI. törvény, melynek értelmében a személyi jövedelemadó 1\%-a felajánlható civil szervezetek támogatására (ugyanis ez sokak számára jelentős bevétel).

4, 1997-ben további szelektív megszorítások, ugyanakkor az indirekt állami támogatás kiszélesítése.

5, Paradigmaváltás 1998-ban: a közhasznú státusz válik a kivételezés legfontosabb eszközévé1.

A millenium utáni egyik legfontosabb esemény az Országgyűlés által 2003. június 23-án megteremtett Nemzeti Civil Alapprogram, melynek fő célja a civil szervezetek, ezen belül pedig magánalapítványok és társadalmi szervezetek pályázatok útján történő támogatásával azok működésének megerősítése, a civil szektor fejlődésének elősegítése. A támogatási forma gyakorlatilag 2012-ig pályázati alapon folyamatosan nyújtott kisebb-nagyobb mértékű ${ }^{2}$, önerő nélküli működési támogatást. Szakmai kiírások is történtek, ezek számukban kevesebb, összegükben többek voltak, és egy-egy program végrehajtását segítették. A támogatási forma sokak szerint a civil törvényi megfelelőségét is erősítette, ugyanakkor számtalan olyan korlátot is tartalmazott, mely a szféra valós aktivitásának növekedését gátolta. ${ }^{3}$ Ezt követően a rendszer átalakult, adminisztrációs jellegét tekintve alapvetően nem (ugyanúgy az EPER rendszeren keresztül lehet pályázni), de sokban egyszerűsödött, némely dolog nem oldódott meg (pl. nincs hiánypótlás, mely különösen lényeges azért, mivel a civil szférában való részvétel nem fóállású foglalkoztatásra alapozott, azaz másod, vagy szabadidős tevékenység). A 2010es kormányváltás eredményeként a politika a civil szervezetek szabályozási környezetének gyökeres

\footnotetext{
${ }^{1}$ A későbbi NCA-ban például szakmai pályázatokon csak közhasznú minősítésű szervezet indulhatott.

${ }^{2} \mathrm{~A}$ támogatási összeg nagysága sokáig az előző évi működés függvényében volt meghatározva, ún. korrigált ráfordítás arányában.

${ }^{3}$ Például nem lehetett cél szerinti eszközt vásárolni. Egyes vélemények szerint a civil szervezetek az évek alatt rengeteg számítógépre, nyomtatóra, stb. tettek szert, de a cél szerinti tevékenység ellátásához nem csak erre lett volna szükség, hanem számos munkaeszközre, gépre, mellyel cél szerint munka végezhető (pl. fúnyíró, sporteszköz)t. Ezt oldották fel már 2011-ben, jelentősen bővítve a támogatások felhasználásának lehetőségeit.
} 
megújulását is célul tűzte ki. 2011. év végén jelent meg az új civil törvény és kapcsolódó további szabályozás", mely a szokásos eljárási gyakorlathoz képest több új követelményt is megfogalmazott, mint például a civil szervezetek fogalma, új civil szervezeti forma bevezetése - a civil társaság megjelenése, a közhasznúság új követelményei, megfelelőség, könyvvezetési követelmények stb. A szabályozás a korábbi NCA-t megszüntette és létrehozta a Nemzeti Együttmúködési Alapot (NEA), mely a korábbi NCA helyére lépve működési és szakmai pályázatokat ír ki és nyújt, többségében önerő köteles támogatások formájában.

A NEA az elért szervezetek számát tekintve egy igen kiterjedt, sokakat elért támogatási lehetőség. A KSH adatai szerint [4 ]2017-ben ez a támogatási forma csak a nonprofit szervezetek bevételeinek mindössze 0,2\%-át adta, és a nonprofit szféra szervezeteinek 7,8\%-a, azaz 4777 szervezet részesült belőle. Ugyanez a forrás tájékoztat arról is, hogy a szféra összes bevételét tekintve 44,4\% az állami támogatás aránya. Itt merül fel a kérdés, hogy vajon azon szervezetek esetében, melyek sporttal foglalkoznak, és egyesület, vagy alapítványi formátumúak (klasszikus civilek, a szféra 87,7\%-át alkotva), azaz klasszikus sportcivil szervezetek, vajon mennyire támogatás kitettek, támogatásfüggők. Vélhetően jelentősen, hiszen csak pl. a TAO támogatás a szféra bevételeinek 2017-ben 5,3\%-át adta a teljes nonprofit szektorra vonatkoztatva. Hatékonyságuk és elterjedtségük nagyon változó, de mindenképpen szerencsésen egészítik ki az állami erőfeszítéseket vagy a piacot [5]. Hasonló korábbi írás szerint [6] szerint a magyarországi civil szektor számos feszültséggel küzd. A költségvetési források eloszlása egyenetlen. Az állami dominancia elve, amely felerősítette a megosztottságot és a szolidaritás hiányát, szintén sok feszültséget szült. A szektor megosztott, az együttműködés helyett inkább a rivalizálás dominál és kialakult egy erős támogatás függőség. A civil szektorban alapvetően egy igen erős differenciálódás zajlott le, emellett kialakult egy szűk, zömmel költségvetési forrásokból gazdálkodó, az államhoz, illetve az önkormányzatokhoz erősen kötődő szervezeti kör, szféra.

Ügyes menedzseléssel egy civil szervezet annyi, amennyit a menedzseri kompetencia belőle kihoz, kevesek számára nyilvánvaló emellett, hogy a civil szervezetek hazai és nemzetközi szinten is értékek, sőt piacosítható értékek, melyek könnyebben juthatnak további forrásokhoz (pl. Uniós támogatások, vállalati, szervezeti társadalmi felelősségvállalás révén adományokhoz), és bizonyos feltételek mellett folytathatnak gazdasági tevékenységet is. Ugyanakkor nem mindenki használja ki a bennük rejlő potenciált, nincs mindenütt tervezés, sok helyen nincs valós emberi erőforrás, hibákkal tarkított az ellenőrzési, beszámolási rendszer, mely mind-mind felveti a kérdést, hogy vajon milyen is a civil szervezetek menedzselése, milyen sajátosságok jellemzik a menedzselési viszonyokat. A menedzselési viszonyokra vonatkozó Hajdú-Bihar megyében végzett kutatások alátámasztják ezen kijelentéseinket, miszerint a szervezetek többségénél nincs foglalkoztatott, az éves bevétel a szervezetek 60\%-nál 500 ezer forint alatti [7]. Erre irányuló vizsgálatok készültek megyei szinten. Ezek sokszor csatornaszervezetek, hasonlóan, mint amikor a csatorna is összegyüjti a vizet, a szervezetek is sokszor ilyen módon-szervezeti formájuknál fogva-gyűjtik össze a felajánlott (pl. közhasznú szerződés kapcsán elérhető adomány), vagy épp elérhető (pl. pályázati támogatások) forrásokat.

\footnotetext{
${ }^{4}$ 2011.évi CLXXV. civil törvény, 2011.évi CVXXXI.törvény, 2011. évi 350. kormányrendeletek együttesen
} biztosítattak törvényi hátteret 


\section{A vizsgálat módszere}

A vizsgálat anyagát egyrészt a 2015-os, eléggé nem részletezett KSH adatbázis adja. A KSH legutóbbi, „A nonprofit szektor legfontosabb jellemzői” fejezeten belül a bővebb információkra kattintva a KSH alapadatbázisa elérhetővé válik, mely 27 excel táblázatban mutatva az adatok és változóik közötti összefüggéseit. Az adatbázis elsősorban a tájékoztatást szolgálja, ugyanakkor annak rendszerezettsége, kezelhetősége lehetővé teszi az adatbázis másodelemzését a vizsgálati szempontjaink alapján. Itthon elfogadott társadalomtudományi kutatásmódszertannal foglalkozó irodalom Babbie: A társadalomtudományi kutatás gyakorlata c. könyve [8]. A szerző szerint „A számítógéppel történő adatelemzés kialakulásával lehetővé vált, hogy egy adatállományt több társadalomkutató közösen használjon...(...) A másodelemzés kifejezés arra vonatkozik, ha a kutató által, máskor, az adott vizsgálatétól eltérő céllal gyűjtött adatokat elemzünk". "Előnyei nyilvánvalóak és óriásiak: olcsóbb és gyorsabb, mint egy eredeti kérdőíves vizsgálatot lefolytatni és abból is hasznot húzhatunk, hogy a legjobb szakemberek munkáját használhatjuk fel. Legnagyobb hátránya az érvényesség, azaz nincs rá garancia, hogy az adatok a mi kutatási kérdéseinkhez is megfelelőek lesznek [8]."

A másodelemzést, mint módszert mi annak kapcsán és amiatt használtuk fel, hogy a KSH által publikált tájékoztató, idősorok és adatbázis (2011 és 2017 között rendszertelenül közzétett) a mi vizsgálatainkhoz viszonylag kevés alapinformációt szolgáltat. A letöltött adatbázis tisztításra került, azaz kizárólag a sport szervezetek, és azon belül is a klasszikus sportcivil szervezetek (alapítványok, illetve egyesületek) adatai lettek kiválogatva, rendezve.

Annak érdekében, hogy mélyebb és átfogó információhoz juthassunk, így a rendelkezésre álló legutolsó adatbázist felhasználva alkalmaztuk a látens változós útelemzéses modellt. A parciális legkisebb négyzetek módszere (Partial Least Sqaures, PLS) egy viszonylag új módszer a látens változós útelemzési modellek becslésére, a kettő kombinációját a továbbiakban LVPLS modellnek nevezzük [9][10]. Az LVPLS egy olyan statisztikai eljárás, amely változóblokkok kapcsolati rendszerének tanulmányozására alkalmas [11]. Minden egyes blokkot, vagy változócsoportot jellemezhetünk egy látens változóval (a főkomponens elemzéshez hasonlóan), majd egyszerű lineáris regresszióval leírjuk a látens változók közötti kapcsolatot. Ilyen módon a módszer a főkomponens elemzés és a regresszió analízis kombinációjaként tekinthető [12]. Egyváltozós regresszióelemzést és Pearson féle korrelációelemzést is alkalmaztunk továbbá a sportcivil szervezetek számának és a klasszikus civilszervezetek bevétele kapcsolatának vizsgálatára.

\section{A vizsgálat eredményei}

A sportcivil szervezetek sajátosságait tekintve az LVPLS modell paraméterbecslései alapján az állami támogatásoknak nagyon erős szignifikáns közvetett és közvetlen hatása van a nyújtott támogatásokra és még nagyobb is a hatás, mint a múködési bevételek esetében. Az állami és magán támogatások 75\%ban hatással vannak a nyújtott támogatásokra, a működési bevételek 20\%-ban hatnak a nyújtott támogatásokra, míg a ráfordítások szerepe 5\%-os és a foglalkoztatottak száma elhanyagolható. 
Ugyanakkor az összes múködési bevétel alakulásában 1\%-ban járul hozzá az önkéntesek száma, 40\%ban a foglalkoztatottak száma és további 59\%-ot jelent az állami támogatások hatása.

Az LVPLS modellben becsült, összevont 6 látens mutatót (nyújtott támogatások, kapott támogatások, önkéntesek, ráfordítások, foglalkoztatás és bevétel) tovább elemeztük régiók szerinti bontásban annak érdekében, hogy a tendenciákat és a regionális különbségeket feltárjuk.

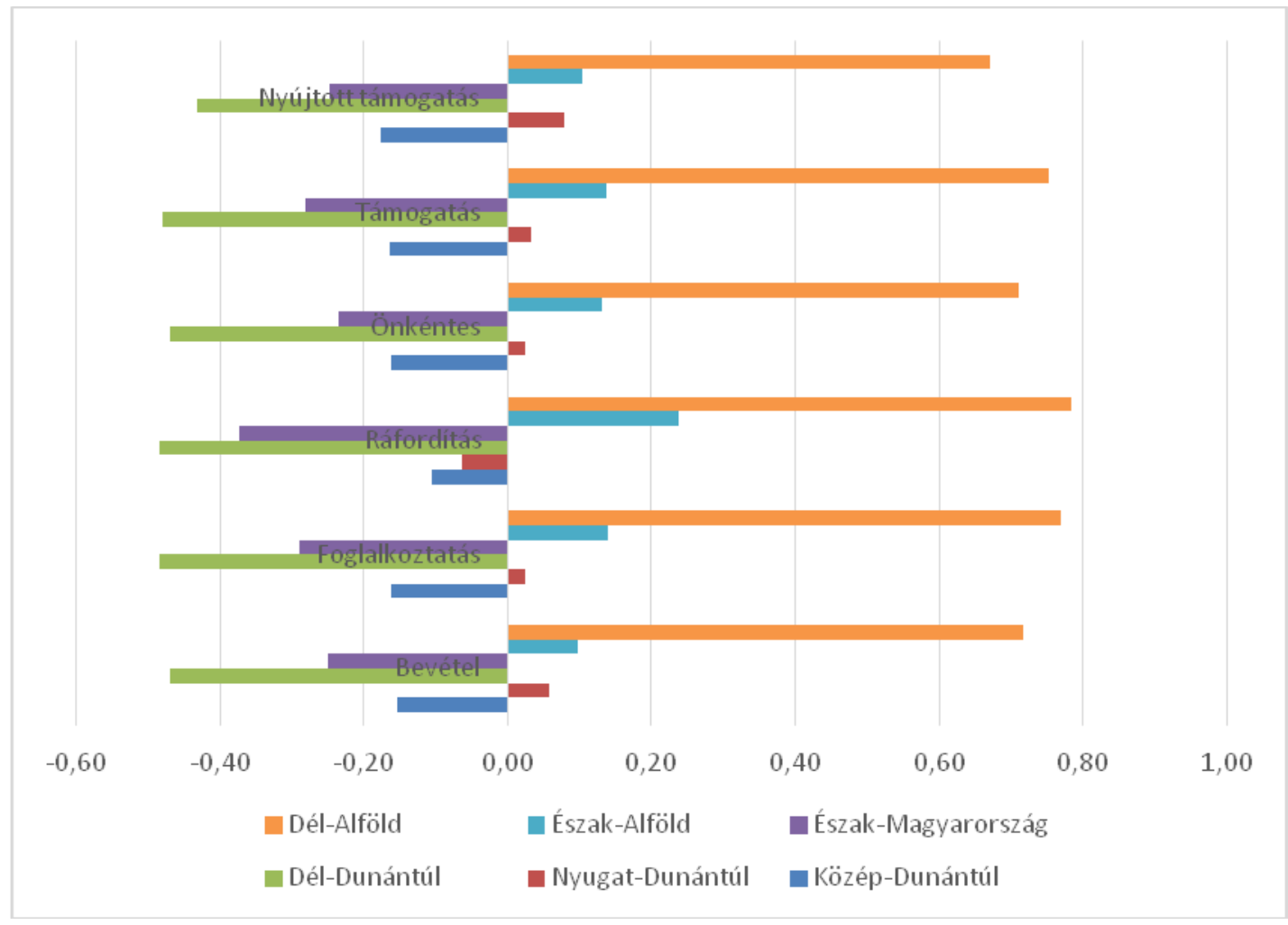

1. ábra: 6 látens mutató elemzése regionális bontásban Forrás: Saját vizsgálatok, 2019.

Az 1. ábrán a 0 az átlagos szintet jelöli, a negatív tartomány az átlagtól vett negatív irányba történő eltérést, a másik a pozitív irányba történő eltérést jelöli. A legjobb helyzetben Dél- és Észak-Alföld van. Legrosszabb helyzetben van Dél-Dunántúl, és Észak-Magyarország. Láthatóan nagyok a különbségek az összevont változók tekintetében, ahol a támogatások vonatkozásában elmondható, hogy az átlagos szintet alapul véve Észak-Alföld, Dél-Alföld, és messze elmaradva tőlük Nyugat-Dunántúl van jobb helyzetben, Dél-Dunántúl pedig messze elmarad a többi régiótól.

A következő, 2. ábrán azt mutatjuk be, hogy a sportcivil szervezetek számának változásával miként alakult a klasszikus civil szervezetek összes bevétele (azaz ezeknek a szervezeteknek a számbeli változása mennyiben befolyásolta a szektor összes bevételét). Ez azért fontos kutatási kérdés, mert 2015-től van TAO és feltehetően jelentős bevételt eredményezett a szektor egészére nézve. 


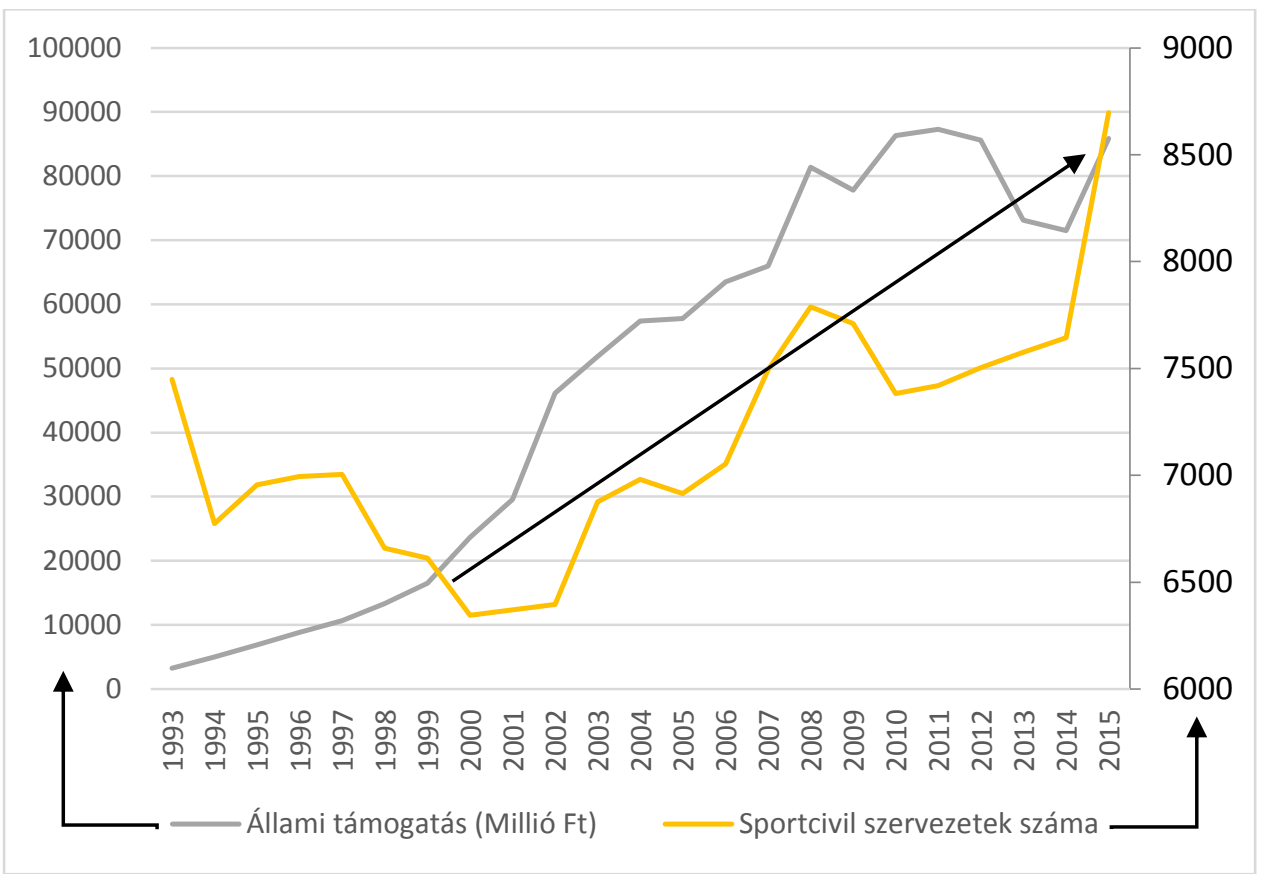

2. ábra: A sportcivilek száma és a támogatások nagyságának összefüggése Forrás: Saját vizsgálatok, 2019.

Az ábra az idősorok tekintetében egyértelműen mutatja a szervezetek számának szoros össszefüggését az elért támogatásokkal. A megyei szintű vonatkozásokat a 3. ábra mutatja be.

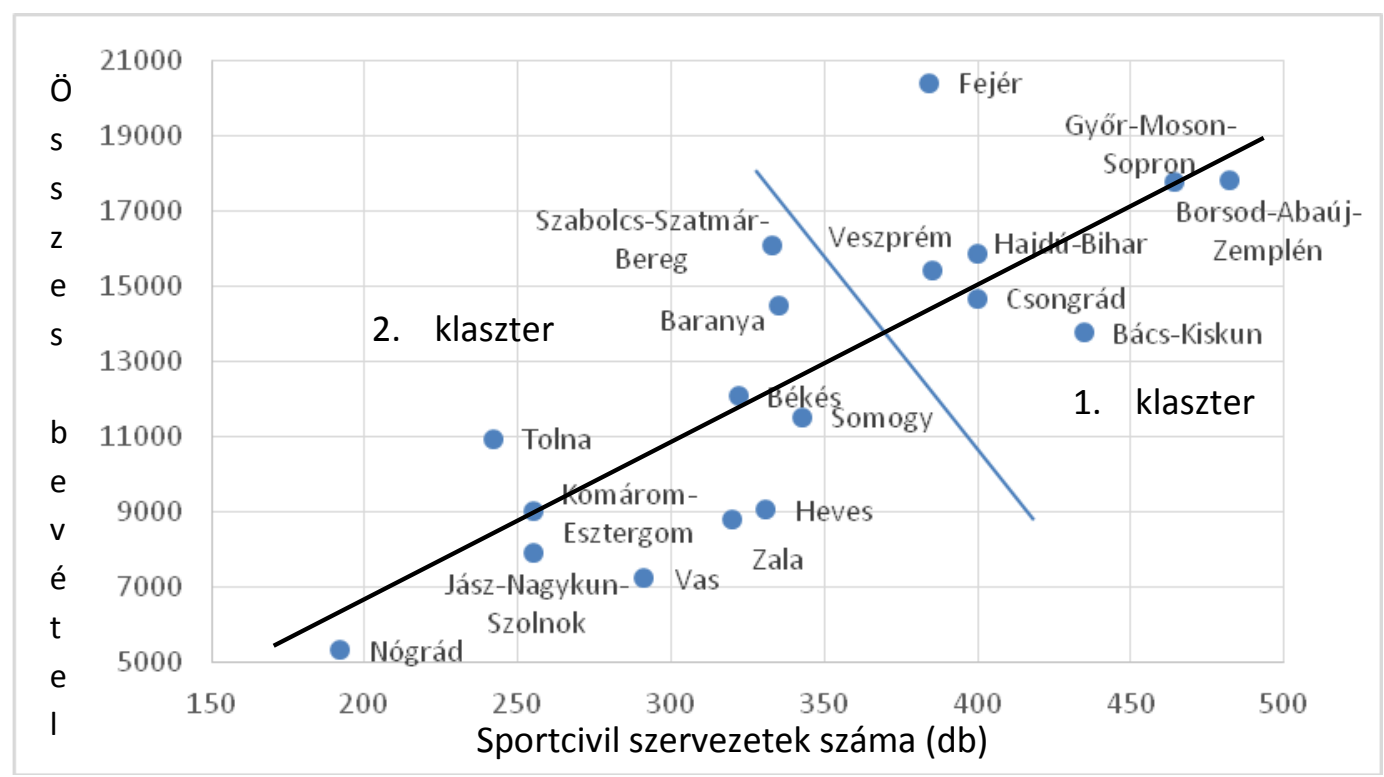

3. ábra: A sportcivil szervezetek számának összefüggése a klasszikus civil szervezetek összes bevételével megyénként Forrás: Saját vizsgálatok, 2019.

Ahogy a korábbi LVPLS modellből is kitűnt, két markáns klasztert lehet kialakítani (Pest megye és a Főváros nem szerepel a vizsgálatban, mert az adatok nagyon eltérőek). Az illesztett hagyományos egyváltozós regresszióelemzés azt mutatta, hogy a szervezetek száma 66\%-ban járult hozzá a klasszikus civil szervezetek bevételének alakulásához. A két tényező korrelációja erős volt $(\mathrm{r}=0,811 ; \mathrm{p}<0,01)$. A regressziós paraméterek és a 95\%-os megbízhatósági tartományok becslésére 
bootstrap szimulációt végeztünk N=2000 elemszámmal. Ez alapján megállapítható, hogy amennyiben a sportszervezetek száma 1-gyel nő, úgy a szektor összbevétele közel 44 [29-54] millió forinttal nő (95\%-os megbízhatósági tartomány).

A korábban említett két támogatási formát tekintve elmondható, hogy a KSH által NCA-nak nevezett (mára NEA) támogatás és a TAO támogatás elérhetősége vélhetően összefüggésben van a sportcivil szervezetekkel. Mi a tanulmány utolsó részében arra kerestük a választ, hogy vajon a sportszervezetek számának növekedése milyen módon befolyásolja a NEA és TAO jellegű fogadott támogatások változását. Miután a KSH-ból származtatott NCA/NEA adatok 2011, 2015, 2016, 2017 évekre álltak rendelkezésre, így a 2011-2015 közötti adatokat lineáris interpoláció révén származtattuk. A TAO esetében kevés, mindössze 2015 és 2017 közötti közétett adatokkal kalkulálhattunk.

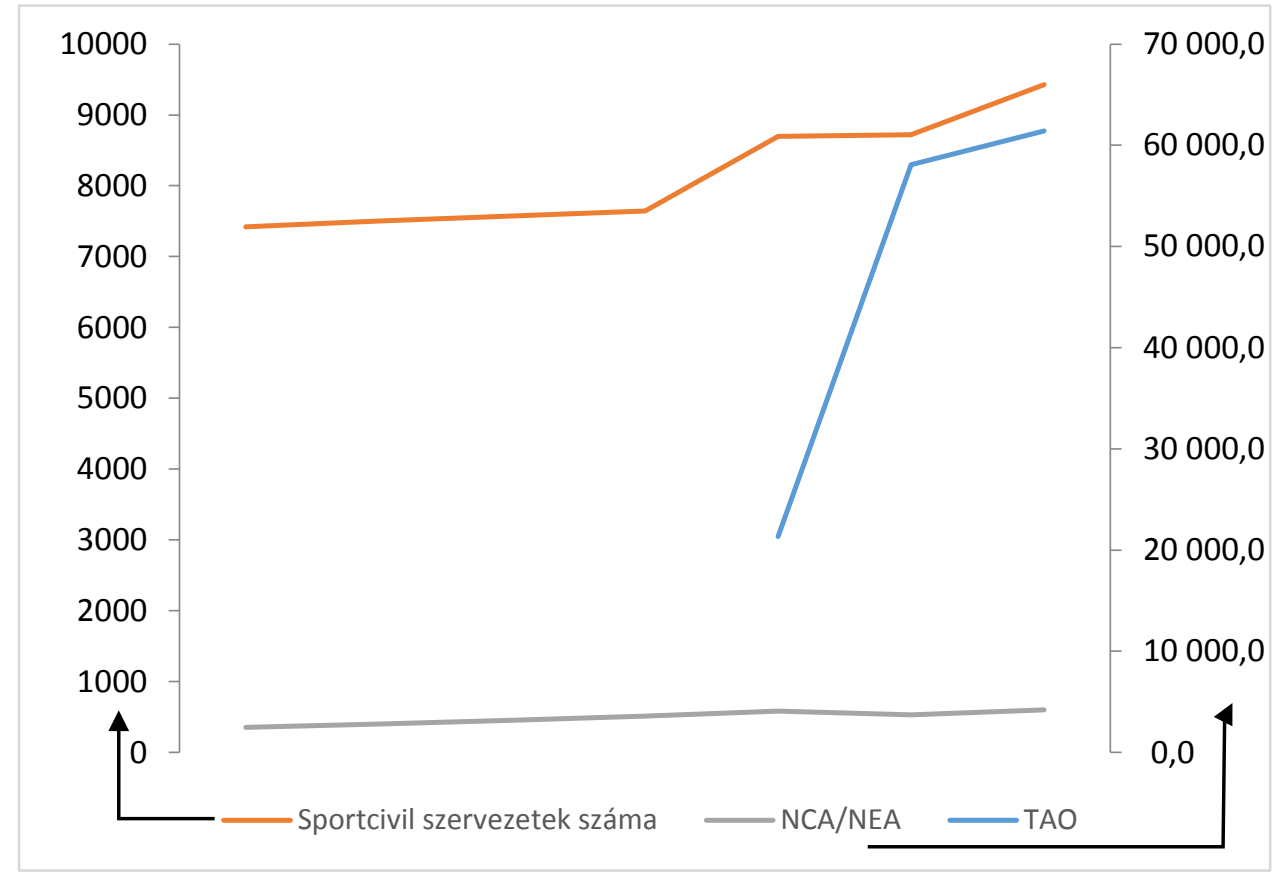

4. ábra: A sportcivil szervezetek számának összefüggése a specifikus támogatásokkal

Forrás: Saját vizsgálatok, 2019.

Az eredmények láthatóan (4.ábra) arra utalnak, hogy a sportcivilek számának növekedésével párhuzamosan az NCA/NEA kisebb dinamikával, a TAO pedig erősebb lendülettel nőtt összegben, azaz elképzelhető a szervezetek számának növekedése a megnövekedett támogatási bevételekkel összefüggésben. Emiatt számszakilag is kerestük a választ arra, hogy vajon a sportcivilek számának növekedése és az egyes specifikus támogatási formák között van- e szorosabb összefüggés. Miután a TAO nemrégen indult támogatás, így a KSH-ból származtatott adatok alapján mindössze 3 támogatási összeg állt rendelkezésre. Az adatokra kiszámoltuk a Pearson-féle korrelációs koefficienst, amely értékére $r=0,589$ ( $p=0.599$ ) adódott. Maga az összefüggés közepesen erős kapcsolatra utalna, de mivel kevés adat állt rendelkezésre, nem adódott szignifikáns összefüggés.

Az NCA/NEA és a szervezetek száma közötti összefüggés feltárása végett Pearson-féle korrelációelemzést végeztünk. Az eredmények azt mutatják, hogy igen szoros összefüggés van a két 
mennyiség között, mivel a korrelációs koefficiens értéke $\mathrm{r}=0.871(\mathrm{p}=0.011)$ nagyon magas volt. Ezt azt jelenti, hogy a sportcivil szervezetek számának növekedése összefüggésben van a fogadott NCA/NEA támogatások nagyságával.

\section{Következtetések}

A tanulmány elsősorban arra az összefüggésre igyekezett rávilágítani, hogy a sportcivil szervezetek utóbbi években történt növekedése és a szféra támogatása között vélhetően létezik összefüggés. Ez nem lehet véletlen, ezek a szervezetek ugyanis formájuknál fogva kifejezetten alkalmasak bizonyos támogatási formák fogadására, épp emiatt lehet jelentős mértékủ a bevételeik között a támogatások aránya. Az eredmények arra utalnak, hogy léteznek régiós különbségek a szervezetek támogatási jellegű megoszlása között. Két specifikus támogatási formát alapul véve az NCA/NEA támogatásokat vizsgálva elmondható, hogy a sportcivil szervezetek számának növekedése összefüggésben van a fogadott NCA/NEA támogatások nagyságával. A TAO, mint újszerű támogatási forma tekintetében a kevés adatra alapozva vélünk egy közepesen erős összefüggést, ahol a további években további adatokra alapozva lehetséges lesz erősebb összefüggést is feltételezni. Összességében tehát úgy tűnik, van összefüggés abban a tekintetben, hogy a támogatási bevételek növekedése mögött a sportcivilek számának növekedése áll.

\section{Hivatkozások}

[1] C. Williams (2011) Management. Cengage Learning, Ohio. 139 p.

[2] J. Gough - K. A. Harper - S. D. Hill - H. M. Selden ed. (2009) Encyclopedia of Management. Cengage Learning, Gale. 619 p.

[3] É. Kuti - I. Sebestyén (2004) Boom and consolodation: The non-profit sector in Hungary. In: Future of Civil Society, e-book, in cooperation of Westfalische Wilhelms-Universitat Münster and Wissenschaftzentrum Berlin für Sozialforschung. 42 p.

[4] KSH nonprofit szektor legfontosabb jellemzői, tájékoztató adatok. http://www.ksh.hu/apps/shop.kiadvany?p_kiadvany_id=1041504\&p_temakor_kod=KSH\&p_lan $\mathrm{g}=\mathrm{HU})$

[5] Zs. Ferge (2000) Elszabaduló egyenlőtlenségek. Hilscher Rezső Alapítvány, Budapest. 97 p.

[6] I. Murányi - A. Szerepi (2005) Civil esélyek Hajdú-Bihar megyében. Hajdúsági Hallgatói Önkormányzatok Kulturális Egyesülete, Debrecen. 54 p.

[7] A. Pierog (2017) Civil szervezetek vezetése- Civil menedzsment? GlobeEdit. Saarbrücken. 173.

[8] E. Babbie (2000) A társadalomtudományi kutatás gyakorlata. Balassi Kiadó, Budapest. pp. 298300.p.

[9] H. Wold (1982) Soft modeling: the basic design and some extensions. In: K. G. Joreskog, \& H. Wold (Eds.), Systems under indirect observation, Part 2. Amsterdam: North-Holland.

[10] H. Wold (1985) Partial least squares. In: S. Kotz, \& N. L. Johnson (Eds.), Encyclopedia of statistical sciences. (pp. 581-591). New York: Wiley. 
International Journal of Engineering and Management Sciences (IJEMS) Vol. 4. (2019). No. 3

DOI: 10.21791/IJEMS.2019.3.12.

[11] W. Chin (1998) The partial least squares approach to structural equation modeling. In G. Marcoulides (Ed.), Modern Methods for Business Research (pp. 295-336). Mahwah/ London: Lawrence Erlbaum.

[12] M. Tenenhaus - V. E. Vinzi - Y. M. Chatelin - C. Lauro (2005) PLS path modeling. Computational Statistics \& Data Analysis. 48 (1) pp. 159-205. 